\title{
Utvidet egenmelding - en vei mot riktigere sykefravær?
}

\author{
Nils Fleten ${ }^{1}$, Line Krane ${ }^{1}$ og Roar Johnsen ${ }^{1,2}$ \\ 1) Institutt for samfunnsmedisin, Universitetet $i$ Tromsø \\ 2) Institutt for samfunnsmedisin, NTNU, Trondheim \\ Correspondence: Nils Fleten, Institutt for samfunnsmedisin, Universitetet i Troms $\varnothing$, N-9037 Tromsø \\ E-post: nils.fleten@uit.no Telefon:+47 77644816 Telefaks: +47 77644831
}

\begin{abstract}
SAMMENDRAG
Bakgrunn: Kunnskapen om hvilken betydning rett til bruk av egenmelding har for sykefravær og sykefraværsmønster er svært begrenset. Denne studien undersøker effekten på korttidsfraværet av en utvidet egenmeldingsordning.

Materiale og metode: Kristiansand kommune med 5700 ansatte (4300 årsverk) innførte 1. april 2002 rett for sine ansatte til å selv dokumentere sykefravær på inntil 50 dager fordelt på 1-10 perioder som et kontrollert intervensjonsforsøk. Dialog med arbeidsplassen var forutsatt for både egenmeldt og legemeldt fravær når fraværet hadde vart i 5 dager.

Resultat: Forsøket viste at egenmelding i stor grad erstattet legemelding for fravær med inntil en ukes varighet. Gjennomsnittslengden av sykefraværet i arbeidsgiverperioden på 16 dager ble forkortet med 0,8 dager. Kurven for tilbakevending til arbeid tilsvarte forventet tilfriskningskurve uten de karakteristiske toppene ved fem, syv og 14 dager som en ser ved legemeldt fravær. Både antall korte sykefravær og andel av ansatte med korttidsfravær økte, men til tross for en forventet registreringseffekt økte ikke sykefraværet som prosent av mulige arbeidsdager i arbeidsgiverperioden.

Konklusjon: Utvidet egenmeldingsrettigheter med strukturert oppfølging fra arbeidsplassen resulterte i et endret mønster for korttidsfravær som kan indikere at dagens ordninger for egenmeldt fravær ikke er tilpasset arbeidstakernes behov.
\end{abstract}

\section{Fleten N, Krane L, Johnsen R. Extended self-certification - a step towards more appropriate sickness absence? Nor J Epidemiol 2009; 19 (2): 223-228.}

\section{ENGLISH SUMMARY}

Background: Knowledge on the consequences of extended self-certification for sickness absence is sparse. This study examines changes in short term sickness absence due to comprehensive extension in the selfcertification scheme.

Aim: To explore any effect on short term sick leave by introducing generous self-certification entitlements combined with structured workplace follow-up.

Method: Kristiansand Municipality with 5700 employees, introduced as a two years trial in April 2002 the right to self certificate sickness absence for until 50 days per year, divided on 1 until 10 periods. Arendal was control municipality. When the sickness absence had lasted for 5 days a structured dialog with the working place was scheduled, regardless self-certification or any medical certificate issued by a physician. Results: The study indicates that extended self-certification halved medical certificates issued by a physician for sickness spells less than a week. The average length of sickness absence limited to the employerfinanced period on 16 days was reduced with 0.8 days. The curve for returning to work corresponded to the expected getting-well curve, i.e. without the typical peaks at 5, 7 and 14 days seen for physician certified sickness spells. Both the numbers of short term sick leave and the portion of employees with short term sick leave increased. Still the sickness absence, as percent of possible workdays during the employerfinanced period, was stable.

Conclusion: The results from the study indicate that extended self-certification reduces the length of the short term sickness absences. This effect on short term sickness absence, proposes that extended selfcertification might be a step towards a more need-adjusted sickness absence pattern.

\section{BAKGRUNN}

Dokumentasjonskravene ved sykefravær varierer mellom ulike land. I de nordiske landene varierer egenmeldingsperioden mellom 0 og 14 dager (1). Det synes ikke å være noen samvariasjon mellom omfanget av sykefravær og hvor sjenerøse egenmeldingsordningene er (2).

Full lønnskompensasjon fra første sykefraværsdag ble i Norge introdusert i 1978. Det inkluderte også retten til egenmeldt sykefravær på inntil tre dager fire ganger i året. Intensjonsavtalen om et inkluderende ar- 
beidsliv (IA) i oktober 2001, inneholdt et mer sjenerøst egenmeldingssystem for arbeidere i bedrifter som var tilsluttet avtalen (3). De kunne benytte egenmelding inntil 24 dager per år, begrenset til 8 dager i en arbeidsgiverperiode på 16 dager. I dag er om lag 56\% av arbeidstakerne tilknyttet bedrifter som er med i IAavtalen (3). For arbeidstakere som ikke kommer inn under IA- avtalen ble egenmeldingsmulighetene noe innskrenket fra 1. juli 2004 da ordningen med annullering av egenmeldingsperioder som gikk rett over $\mathrm{i}$ legemeldt fravær opphørte (4).

Ingen av disse reformene ble utprøvd i pilotstudier eller designet med tanke på å evaluere effekter på korttidsfravær eller sykefravær generelt. I utvalget av norske bedrifter som rapporterer egenmeldt fravær til Statistisk sentralbyrå økte det egenmeldte fraværet med 0,2 prosentpoeng fra 2001 til 2008, en økning fra 0,7 til $0,9 \%$ for menn og fra 0,9 til $1,1 \%$ for kvinner (5). I andre kvartal 2008 utgjorde egenmeldt fravær 12\% av sykefraværet mot 10\% i andre kvartal 2001 (3).

Småskalaforsøk med forlenget egenmelding inntil en uke har vist reduksjon i totalfraværet (6). Taylor viste på 1960-tallet at utvidet egenmelding førte til kortere sykefraværstilfeller sammenliknet med legemeldt fravær (7). Etter dette forsøket er lite publisert om virkninger av endringer i egenmeldingsordninger, og foreliggende statistikk taler for at korttidsfraværet har vært rimelig stabilt i Norge fra 1978 (8).

Når så regjeringen i 2000 vedtok å støtte studier som ville prøve ut utvidet egenmelding (9), var det et faglig og økonomisk grunnlag for storskalaforsøk.

Målet med studien var å studere hvordan utvidet egenmelding kombinert med strukturert og systematisk dialog mellom arbeidstaker og arbeidsgiver påvirket korttidsfraværet i arbeidsgiverperioden.

\section{Materiale OG Metode}

Kristiansand kommune med 5700 ansatte, tilsvarende 4300 årsverk, vedtok å prøve ut utvidet egenmelding $\mathrm{i}$ 2001. For å avklare hva arbeidstakeres bruk av egenmeldt fravær vil være, uavhengig av vedtatte rammer, vedtok den lokale styringsgruppen en årlig egenmeldingskvote på 50 dager fordelt på inntil 10 fraværsperioder. Ethvert sykefravær, legemeldt eller egenmeldt, på minst fem dager skulle utløse en henvendelse fra arbeidsgiver. Innholdet $\mathrm{i}$ og formen på henvendelsen, var avtalt med arbeidstakere og arbeidsledere.

Forsøket startet med tre måneders pilot i kommunens teknisk sektor hvor skjema, registreringsrutiner og samtaleformer ble utprøvd. Etter mindre justeringer av rutinene ble egenmelding implementert for alle ansatte i Kristiansand kommune fra april 2002 (10).

Arendal kommune ble valgt å være kontrollkommune etter å ha meldt sin interesse for å delta i prosjektet, på grunn av sin geografiske nærhet og egenskaper som fylkets administrative senter. Med fokus på fravær som prosent av mulige fraværsdager ble det avtalt at Arendal bare skulle levere summariske kjønns- og lengdespesifikke fraværsdata på enhetsnivå. Dette medfører dessverre klare begrensninger $i$ analyser av endringer $i$ lengde og mønster av fravær. For fravær utover tre dager er derfor endringer over studieperioden analysert som før-etter sammenligninger bare i Kristiansand.

For fravær av 1-3 dagers varighet i Arendal er lengden estimert som antall arbeidsdager dividert på tilfeller, og korrigert for gjennomsnittlig stillingsprosent. Fraværslengden i Kristiansand er beregnet som differansen mellom siste fraværsdato minus dato for fraværsstart pluss en dag.

For beregning av antall fravær per ansatt er antall fravær i året dividert på ansatte per 1. oktober. Andelen ansatte med registrert fravær er beregnet på basis av ansatte med minst to måneders sammenhengende ansettelse det aktuelle år.

Prosjektet skulle vare fram til 31. mars 2004, men Kristiansand kommune fikk forlenget dispensasjon for egenmeldingsforsøket, foreløpig ut 2009. Denne studien er basert på data om korttidsfraværet i perioden 2000 til 2005.

\section{Statistikk}

Endringer i lengde av sykefravær er analysert med tosidig t-test og presentert med 95\% konfidensintervall (95\% KI). Frekvensfordelingen for fraværslengde er vist som tilbake til arbeid (RTW) kurver.

\section{ReSUltat}

\section{Fravar av 1-3 dagers varighet}

Innføringen av utvidet egenmeldingsordning for de kommunalt ansatte i Kristiansand fra april 2002, resulterte i en økning på 1441 registrerte 1-3 dagers fravær fra 2001 til 2003 (tab 1). I samme periode økte gjennomsnittlig antall 1-3 dagers fravær per år med 0,21 hos menn og 0,31 hos kvinner, (tab 1). Gjennomsnittslengden av 1-3 dagers fraværene ble redusert med knappe 0,2 dager, litt mere for menn enn kvinner. Den estimerte gjennomsnittslengden av 1-3 dagers fraværene i Arendal var stabil blant kvinner, men viste en liten reduksjon for menn i perioden 2001 til 2003 (ikke vist $\mathrm{i}$ tabell). Økningen i antall registrerte 1-3 dagers fravær var langt lavere i Arendal enn i Kristiansand, henholdsvis $6 \%$ og $26 \%$.

I Kristiansand var det en klar økning fra $87 \%$ til 93\% i hvor stor andel av 1-3 dagers fraværene som var egenmeldte (tab 1). I Arendal var andelen av 1-3 dagers fraværene som var egenmeldte stabilt på rundt 90\%. Antall årlige legemeldte 1-3 dagers fravær ble $\mathrm{i}$ Kristiansand redusert fra gjennomsnittlig 673 i 2000/2001 til 484 i 2004/2005.

\section{Fravaer av 4-16 dagers varighet}

Egenmelding ble i liten grad brukt ved fravær utover én uke. Endringene i antall 4-16 dagers fravær per ansatt var beskjedne (tab 2). Mens antallet var konstant, ble fraværene kortere med en gjennomsnittlig reduksjon i lengde på rundt én dag for menn og 0,7 dager for kvinner. 
Tabell 1. Antall sykefravær, andel sykefravær som var egenmeldt og gjennomsnittlig lengde (mean i dager med 95\% KI) av sykefravær i lengdekategoriene 1-3 dager og 4-16 dager med undergruppen 4-7 dager, før og etter innføring av utvidet egenmeldingsordning for kommunalt ansatte i Kristiansand 1. april 2002.

\begin{tabular}{lcccccc}
\hline & 2000 & 2001 & 2002 & 2003 & 2004 & 2005 \\
\hline Fravær 1-3 dager & & & & & & \\
$\quad$ N fravær & 5072 & 5428 & 6212 & 6967 & 6131 & 7640 \\
Fravær per ansatt & 0,95 & 1,01 & 1,16 & 1,29 & 1,04 & 1,27 \\
Andel egenmeldt \% & 87,8 & 86,7 & 92,2 & 92,1 & 91,7 & 91,9 \\
$\quad$ Mean, dager & 1,81 & 1,80 & 1,68 & 1,64 & 1,63 & 1,61 \\
95\% konfidensintervall & $1,79-1,83$ & $1,78-1,82$ & $1,66-1,70$ & $1,62-1,66$ & $1,62-1,65$ & $1,59-1,63$ \\
Fravær 4-16 dager & & & & & & \\
$\quad$ N fravær & 2371 & 2536 & 2414 & 2690 & 2635 & 2600 \\
Fravær per ansatt & 0,44 & 0,47 & 0,45 & 0,50 & 0,45 & 0,44 \\
Andel egenmeldt \% & 1,2 & 1,3 & 26,8 & 37,2 & 42,5 & 42,7 \\
Mean, dager & 8,54 & 8,47 & 8,06 & 7,82 & 7,70 & 7,78 \\
$\quad$ 95\% konfidensintervall & $8,40-8,69$ & $8,33-8,61$ & $7,92-8,21$ & $7,68-7,95$ & $7,56-7,84$ & $7,64-7,91$ \\
Undergruppe 4-7 dager & & & & & & \\
$\quad$ N fravær & 1213 & 1327 & 1366 & 1604 & 1565 & 1519 \\
Fravær per ansatt & 0,23 & 0,25 & 0,25 & 0,30 & 0,27 & 0,26 \\
Andel egenmeldt \% & 2,1 & 2,5 & 46,3 & 50,6 & 56,9 & 57,9 \\
Mean, dager & 5,57 & 5,56 & 5,29 & 5,26 & 5,14 & 5,20 \\
95\% konfidensintervall & $5,50-5,63$ & $5,50-5,62$ & $5,23-5,35$ & $5,21-5,32$ & $5,09-5,19$ & $5,14-5,26$ \\
\hline
\end{tabular}

Tabell 2. Antall sykefravær, andel sykefravær som var egenmeldt og gjennomsnittlig lengde (mean i dager med 95\% KI) av fravær i lengdekategoriene 1-3 dager og 4-16 dager med undergruppen 4-7 dager, før (2001) og etter (2003 og 2005) innføring av utvidet egenmeldingsordning for kommunalt ansatte i Kristiansand 1. april 2002.

\begin{tabular}{lcccccc}
\hline & \multicolumn{2}{c}{2001} & \multicolumn{2}{c}{2003} & \multicolumn{2}{c}{2005} \\
\cline { 2 - 6 } & Menn & Kvinner & Menn & Kvinner & Menn & Kvinner \\
\hline Fravær 1-3 dager & & & & & & \\
$\quad$ N fravær & 1051 & 4377 & 1322 & 5645 & 1443 & 6197 \\
Fravær per ansatt & 0,81 & 1,07 & 1,02 & 1,38 & 1,03 & 1,35 \\
Andel egenmeldt \% & 89,1 & 86,1 & 94,6 & 91,5 & 94,5 & 91,3 \\
Mean dager & 1,87 & 1,79 & 1,72 & 1,62 & 1,66 & 1,60 \\
95\% konfidensintervall & $1,82-1,92$ & $1,76-1,81$ & $1,68-1,77$ & $1,60-1,64$ & $1,62-1,70$ & $1,58-1,62$ \\
Fravær 4-16 d & & & & & & \\
N fravær & 438 & 2098 & 510 & 2180 & 548 & 2052 \\
Fravær per ansatt & 0,34 & 0,51 & 0,39 & 0,53 & 0,40 & 0,45 \\
Andel egenmeldt \% & 2,5 & 1,1 & 46,1 & 35,1 & 52,3 & 40,2 \\
Mean dager & 8,44 & 8,48 & 7,55 & 7,88 & 7,49 & 7,85 \\
95\% konfidensintervall & $8,10-8,78$ & $8,32-8,63$ & $7,24-7,86$ & $7,73-8,03$ & $7,20-7,78$ & $7,70-8,00$ \\
Undergruppe 4-7 dager & & & & & & \\
N fravær & 236 & 1091 & 328 & 1276 & 335 & 1184 \\
Fravær per ansatt & 0,18 & 0,27 & 0,25 & 0,31 & 0,24 & 0,26 \\
Andel egenmeldt \% & 4,7 & 2,0 & 58,0 & 48,7 & 67,4 & 55,3 \\
Mean dager & 5,56 & 5,55 & 5,20 & 5,28 & 5,05 & 5,24 \\
95\% konfidensintervall & $5,42-5,71$ & $(5,49-5,62)$ & $5,08-5,32$ & $5,21-5,34$ & $4,93-5,16$ & $5,18-5,31$ \\
\hline
\end{tabular}

Gjennomsnittslengden for 4-16 dagers fraværene ble redusert med 0,8 dager fra 2001 til 2005. Denne reduksjonen i lengde av 4-16 dagers fraværene ble oppveid av økt antall 1-3 dagers fravær, slik at det gjennomsnittlige sykefraværet målt som dagsverk per årsverk for hele arbeidsgiverperioden på 1-16 dager var stabilt med 7,24 dager både i 2001 og 2005.

Antall 1-16 dagers fravær per ansatt økte jevnt fram til 2003, for så å vise en tydelig reduksjon i 2004 (tab 1). Reduksjonen var knyttet til antall egenmeldte 1-3 dagers fravær. I egenmeldingsstatistikken fra SSB fin- nes ikke en tilsvarende reduksjon i 2004.

Både menn og kvinner viste en betydelig overgang fra legemeldt til egenmeldt fravær for sykefravær med varighet 4-7 dager (tab 2). Fra 2001 til 2005 økte andelen egenmeldte $4-7$ dagers fravær fra $2 \%$ til $55 \%$ for kvinner og fra $5 \%$ til $67 \%$ for menn. I samme periode gikk gjennomsnittslengden av 4-7 dagers fraværene ned med 0,3 dager for kvinner og 0,5 dager for menn.

Antall årlige legemeldte 4-7 dagers fravær ble halvert fra gjennomsnittlig 1244 i 2000/2001 til 618 i $2004 / 2005$. 


\section{Monster i fravaret av 1-16 dagers varighet}

Figur 1 viser endringer i frekvensfordeling av sykefravær med varighet 1-16 dager. De største endringene etter utvidet egenmelding var økt andel en dags sykefravær, og redusert andel sykefravær med tre, sju og fjorten dagers varighet. I gjennomsnitt økte andel en dags fravær fra $29,8 \%$ i $2000 / 2001$ til $38,7 \%$ i $2004 /$ 2005. I samme periode ble andelen tre dagers fravær redusert fra 16,5 til $11,2 \%$, sju dagers fravær redusert fra 5,0 til $3,0 \%$ og andelen fjorten dagers fravær fra 2,4 til $1,5 \%$.

Antall legemeldte fravær med en dags varighet var stabilt, med til sammen 371 fravær i 2000/ 2001, mot 372 i 2004/2005. Andelen av de legemeldte 1-16 dagers fraværene som varte kun en dag økte fra 6,0 til $9,9 \%$. Antallet legemeldte sju dagers fravær ble redusert fra gjennomsnittlig 382 i 2000/2001 til 299 i $2004 / 2005$, noe som tilsvarer en relativ reduksjon fra 12,3 til 10,6\%. I 2000/2001 viste legemeldt fravær av sju dagers varighet en overhyppighet på 1,8 sammenlignet med seks og åtte dagers fravær. I 2004/2005 var tilsvarende overhyppighet 1,6.

Kurven for egenmeldt fravær for 2004-2005 viser et langt jevnere forløp enn for det legemeldte fraværet. Andelen av egenmeldte fravær som varte tre dager ble redusert fra $22,1 \%$ i $2000 / 2001$ til $12,1 \%$ i 2004/2005. Antallet årlige egenmeldte fravær av 3 dagers varighet ble tilsvarende redusert fra 1020 til 902.

Andelen av de ansatte med legemeldt 1-16 dagers fravær ble redusert med $20 \%$ for menn og $16 \%$ for kvinner fra 2001 til 2005 (tab 3). Tilsvarende økte andelen menn som hadde registrert egenmeldt fravær med $36 \%$ og andelen kvinner med $20 \%$.

\section{DISKUSJON}

Et intervensjonsfors $ø \mathrm{k}$ i stor skala med betydelig utviding av egenmeldingsrettigheter resulterte i økning i antall korte fravær samtidig som hvert fravær ble kortere. Gjennomsnittlig ble hvert fravær i arbeidsgiverperioden redusert med 0,8 dager, mens sykefraværet som prosent av mulige arbeidsdager $i$ arbeidsgiverperioden var stabilt. For fravær som varte 4-7 dager ble antall legemeldte fravær halvert i perioden 2000 til 2005. Kurven for når fravær i arbeidsgiverperioden ble avsluttet viste en utvisking av den karakteristiske overhyppighet av fravær med fem, sju eller fjorten dagers varighet, typisk ved legemeldt fravær.

Resultatene i denne studien er basert på Kristiansand kommune sitt register over ansatte og deres sykefravær. Tilbakemeldinger ved prosjektstart indikerte varierende praksis med registreringen av korttidsfravær mellom de enkelte arbeidsplasser (11). Med økt oppmerksomhet på registreringen i selve forsøksperioden, kan noe av den initiale oppgangen i antall fravær av 1-3 dagers varighet være en registreringseffekt. Tilsvarende nedgang i antall 1-3 dagers fravær i 2004, ved forsøkets slutt, ville da kunne forklares med redusert krav til registrering igjen. Nedgangen var imidlertid forbigående og falt sammen med tilsvarende nasjonale trend med redusert sykefravær i 2004 (5). Nedgangen nasjonalt har vært knyttet til innføring av aktivitetsplikt etter åtte ukers fravær 1. juli 2004 og endringer i leger sykmeldingspraksis (12). Reduksjonen i antall fravær av 1-3 dagers varighet i 2004 i denne studien, kan vanskelig tilskrives endring $i$ legenes praksis da det var flere legemeldte fravær av 1-3 dagers varighet i 2004 enn både i 2003 og 2005. Mer sannsynlig er det at den offentlige debatten kan ha påvirket korttidsfraværet, synliggjort i det egenmeldte fraværet. Dette vil være i samsvar med effekt av populasjonsbaserte informasjonskampanjer om sykefravær (13). Fravær av tilsvarende nedgang i Statistikkbankens rapportering av egenmeldt fravær kan tale for registreringseffekt (5). Alternative forklaringer kan være at utvalget arbeidsplasser som rapporterer egenmeldt fravær har betydning, eller at tradisjonelle fraværskulturer er mindre påvirkbare av en offentlig debatt, i samsvar med stabiliteten i korttidsfraværet fra sykelønnsreformen i 1978 (8).

En samlet vurdering av 1-3 dagers fravær i Kristiansand kommune tilsier at det har vært en økning $i$ antall fravær, og at deler av økningen må tilskrives bedret registreringsrutiner.

Utvisking av den karakteristiske overhyppighet av fravær med fem, sju eller fjorten dagers varighet, typisk ved legemeldt fravær, er helt i tråd med Taylor sine funn fra 1960-årene (7). Han viste at forskjellen i fravær mellom arbeidere og funksjonærer gikk ned når arbeiderne fikk samme egenmeldingsrettigheter, og det var en klar tilbakegang av fravær som ender på fredag eller søndag, de karakteristiske fem- og sju-dagers toppene i legemelt fravær (14). Når resultatene i Taylors mannsdominerte oljeraffineri reproduseres i studien av kvinnedominerte kommunale arbeidsplasser i Kristiansand, styrker det generaliserbarheten av resultatene.

For sykefravær mellom 4-7 dager kan overgangen fra lege- til egenmeldt fravær forklare forkortningen i gjennomsnittslengde vi observerte for det samlede korttidsfraværet på 1-16 dager. Legenes sykmelding vil være mer normativt preget enn egenmeldt fravær, der det å kjenne seg arbeidsfør er mer avgjørende enn legens "råd" for tilbakegang til arbeid.

For fravær utover en uke var overgangen fra legemeldt til egenmeldt fravær av mindre omfang. Dette samsvarer med de ansatte sine svar i evalueringen der $81 \%$ svarer at de foretrekker legemelding ved fravær utover en uke både i 2002 og 2004 (15). Faren for at ordningen kan misbrukes framstod som viktig argument for de som var tvilende til om det var en god ordning, samtidig som to tredjedeler mente at ordningen gjorde det lettere å ivareta helsa (15). Dette taler for at legitimeringsbehovet er viktig for motviljen mot bruk av egenmelding utover en uke.

Reduksjon $\mathrm{i}$ antall egenmeldte fravær av tre dagers varighet støtter en hypotese om at restriktive ordninger kan gi opphav til rettighetstenking, med en ide om at en mister noe om en ikke tar tre dager når en først 


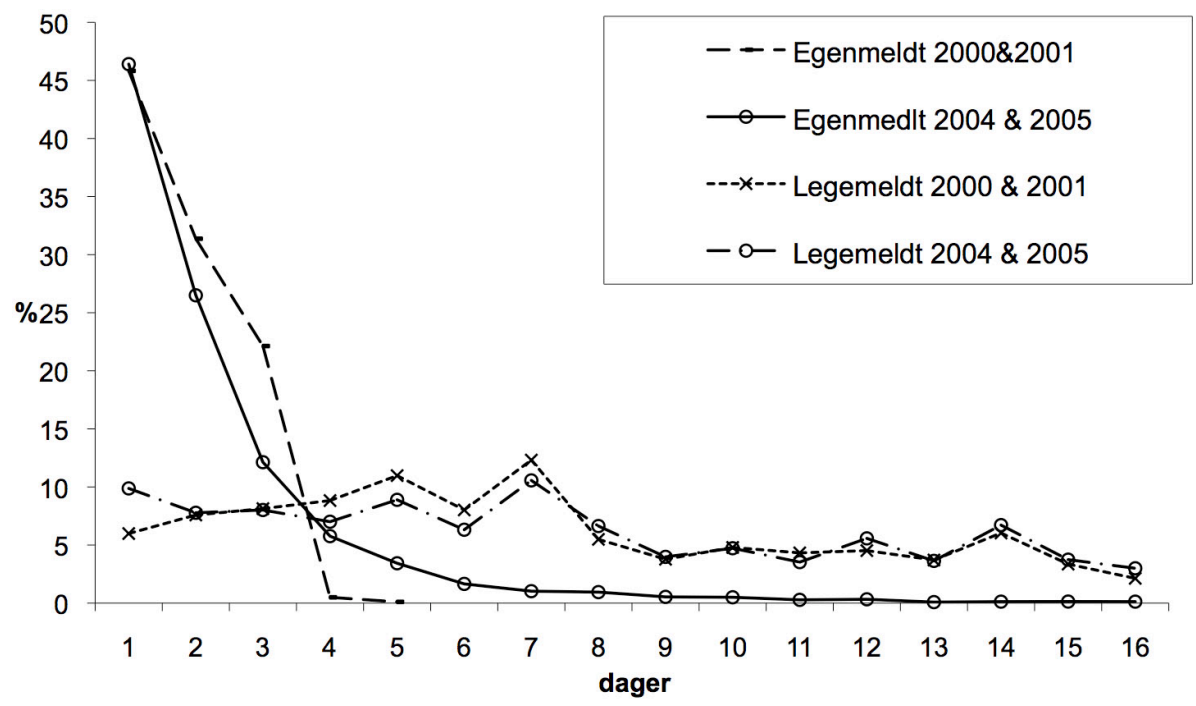

Figur 1. Prosentvis fordeling av egenmeldt og legemeldt sykefravær i arbeidsgiverperioden etter varighet $\mathrm{i}$ dager før og etter innføring av utvidet egenmeldingsordning for kommunalt ansatte i Kristiansand 1. april 2002.

Tabell 3. Andel (antall og \%; 95\% KI) av de ansatte i Kristiansand kommune som hadde egenmeldt og legemeldt sykefravær av 1-16 dagers varighet i 2001, 2003 og 2005, og andel (\%; 95\% KI) av ansatte som hadde ett eller flere legemeldte fravær, henholdsvis ett eller flere egenmeldte sykefravær.

\begin{tabular}{lcccccc}
\hline & \multicolumn{2}{c}{2001} & \multicolumn{2}{c}{2003} & \multicolumn{2}{c}{2005} \\
\cline { 2 - 6 } & Menn & Kvinner & Menn & Kvinner & Menn & Kvinner \\
\hline Ansatte personer & 1533 & 4736 & 1531 & 4885 & 1463 & 4869 \\
Antall med sykefravær & 851 & 3296 & 893 & 3509 & 939 & 3635 \\
Andel ansatte med sykefravær & 55,5 & 69,6 & 58,3 & 71,8 & 64,2 & 74,7 \\
\%; 95\% KI & $53,0-58,0$ & $68,3-70,9$ & $55,9-60,8$ & $70,6-33,1$ & $61,7-66,6$ & $73,4-75,9$ \\
Andel ansatte benyttet & 32,1 & 48,5 & 28,3 & 43,4 & 25,8 & 40,6 \\
legemelding \% & $29,8-34,4$ & $47,0-49,9$ & $26,0-30,5$ & $42,0-44,8$ & $23,5-28,0$ & $39,3-42,0$ \\
Andel ansatte benyttet & 39,3 & 49,6 & 47,3 & 55,9 & 53,6 & 59,5 \\
egenmelding \% & $36,9-41,8$ & $48,2-51,0$ & $44,8-49,8$ & $54,6-57,3$ & $51,0-56,1$ & $58,1-60,9$ \\
Benyttet kun en egenmelding & 62,0 & 58,1 & 46,0 & 40,1 & 44,8 & 41,0 \\
av de med egenmelding \% & $58,1-65,9$ & $56,1-60,1$ & $42,4-49,6$ & $38,2-41,9$ & $41,3-48,3$ & $39,3-48,8$ \\
Andel ansatte med mer enn & 0,1 & 0,1 & 2,0 & 2,9 & 2,1 & 3,0 \\
5 egenmeldinger & & & $1,3-2,8$ & $2,5-3,4$ & $1,4-2,9$ & $2,5-3,4$ \\
Gjennomsnitt antall fravær hos & 2,10 & 2,49 & 2,47 & 2,83 & 2,41 & 2,70 \\
personer med registrert sykefravær & $2,01-2,20$ & $2,43-2,55$ & $2,35-2,59$ & $2,75-2,90$ & $2,39-2,53$ & $2,64-2,77$ \\
\hline
\end{tabular}

benytter en egenmelding. Redusert andel egenmeldinger med onsdag som siste fraværsdag vurderes å støtte en slik hypotese (16).

Når antall legemeldte fravær i de første 16 dagene årlig reduseres med omlag 1100 fravær må dette forventes ha betydning for legesøkingsadferd og et betydelig antall konsultasjoner hos lege vil være spart i denne populasjonen på 5700 ansatte. I en evaluering av egenmeldingsordningen i Kristiansand viser Paulsen at de ansatte synes det er lettere å ivareta egen helse med en utvidet egenmeldingsordning (15). Dette, sammen med en tydelig nedgang i totalt sykefravær for arbeidstakere over 50 år og redusert tilgang til Kommunens pensjonskasse (16), taler imot negative helseeffekter av utvidet egenmeldingsordning. I hvilken grad endringene i mønsteret av korttidsfravær påvirker totalfraværet gir studien ikke entydig svar på. En mu- lig effekt kan være økning av såkalt mestringsfravær der den ansatte tar seg inn med korte fravær uten å søke lege med råd om lengre fravær som resultat (6). Bruk av egenmelding vil også kunne fremme dialogen på arbeidsplassen og støtte den effekten dialogen kan ha på totalfraværet (16).

\section{OPPSUMMERING}

Betydelig utvidet egenmelding resulterte $\mathrm{i}$ :

- At flere ansatte benyttet egenmelding

- En overgang fra legemeldt til egenmeldt fravær som forkortet sykefraværet

- At fraværsmønsteret fulgte naturlig tilfriskningsmønster og ikke ukeslutt og ukestart

- At det totale fraværet de første 16 dagene, beregnet som dagsverk per årsverk, ble lite påvirket 


\section{KONKLUSJON}

Utvidet egenmeldingsrettigheter med strukturert oppfølging fra arbeidsplassen resulterte i et endret mønster for korttidsfravær som kan indikere at dagens ordning for egenmeldt fravær ikke er tilpasset arbeidstakernes behov.

\section{REFERANSER}

1. Brage S, Krohg M, Klockars M, Mikaelsson B, Permin H, Thorlacius S. [Health and social insurance in Nordic countries]. Tidsskr Nor Laegeforen 2002; 122 (15): 1486-91.

2. Nordiske initiativer til nedbringelse av sygefravær. http://www.norden.org/da/publikationer/publikationer/ 2005-524 2005.

3. Ose SO, Bjerkan AM, Pettersen KH, Johnsen A, Lippestad J, Paulsen B, et al. Evaluering av IA-avtalen (2001-2009). Trondheim: SINTEF; 2009 Jun.

4. Folketrygdloven Rundskriv § 8-23. http://www.nav.no/rettskildene/Rundskriv/147592.cms.

5. Statistics Norway. Statistics by subject 06.02 Arbeidsmiljø og sykefravær (http://www.ssb.no/emner/06/02/).

6. Sykefravær og uførepensjonering. Et inkluderende arbeidsliv [Sickness absence and disability pensioning]. Oslo; 2000 Sep 15. Report No: NOU 2000; 27.

7. Taylor PJ. Self-certification for brief spells of sickness absence. Br Med J 1969; 1 (5637): 144-7.

8. Gjesdal S. [Sickness absence incidence in Norway 1975-2002]. Tidsskr Nor Laegeforen 2005; 125 (6): 742-5.

9. Sosial- og helsedepartementet. Ot prp nr 6 (1999-2000) Om lov om endringer i folketrygdloven og i enkelte andre lover. 2000.

10. Romedal BE. Prosjekt egenmelding Kristiansand kommune Prosjektleders evalueringsrapport. Kristiansand: Kristiansand kommune; 2005.

11. Fleten N, Johnsen R. Prosjekt egenmelding Kristiansand kommune. Evaluering av kontrollert intervensjonsforsøk i stor skala, med utvidet rett til egenmelding i kombinasjon med økt og formalisert samhandling mellom arbeidstaker og arbeidsplassen ved sykefravær. Tromsø: Institutt for samfunnsmedisin, Universitetet i Tromsø; 2005. Rapport Nr. 79.

12. Brage S, Kann I C. Fastlegers sykmeldingspraksis II - Regelendringer. Rikstrygdeverket Utredningsavdelingen; 2006. Report No: 06/2006.

13. Buchbinder R, Jolley D, Wyatt M. Population based intervention to change back pain beliefs and disability: three part evaluation. BMJ 2001; 322 (7301): 1516-20.

14. Brage S, Thune O. Friskmeldt fra mandag. Arbeids og velferdsdirektoratet; 2009. Report No: 2-2008.

15. Paulsen B. Evaluering av egenmeldingsforsøket i Kristiansand - ansattes erfaringer og vurderinger. Trondheim: Sintef Helse; 2005. Rapport STF78 A055011.

16. Fleten N, Johnsen R. Etter prosjekt egenmelding Kristiansand kommune. http://kristiansand kommune no/_bin/844F977D-802B-477F-BE6B-AA6C2C27C161 pdf 2007. 